\title{
Immune responses induced by different vaccine platforms against coronavirus disease-19
}

\author{
Eknath D. Ahire* ${ }^{*}$, Sanjay J. Kshirsagar \\ Department of Pharmaceutics, MET's Institute of Pharmacy, Bhujbal Knowledge City, Affiliated to Savitribai Phule Pune \\ University, Nashik 422003, MS, India
}

*Correspondence: Eknath D. Ahire, Department of Pharmaceutics, MET's Institute of Pharmacy, Bhujbal Knowledge City, Affiliated to Savitribai Phule Pune University, Nashik 422003, MS, India. eknathahire05@gmail.com

Academic Editor: Wangxue Chen, Human Health Therapeutics Research Center, Canada

Received: May 31, 2021 Accepted: August 30, 2021 Published: October 31, 2021

Cite this article: Ahire ED, Kshirsagar SJ. Immune responses induced by different vaccine platforms against coronavirus disease-19. Explor Immunol. 2021;1:243-57. https://doi.org/10.37349/ei.2021.00016

\begin{abstract}
There have been significant developments in the design of nanostructured scaffolds for eliciting robust immune responses named vaccine. The technique is to produce strong immune responses is to manipulate the appearance of a pathogen. Subsequently pathogens such as viruses and bacteria often demonstrate of multiple copies of ligands on their surfaces, the immune system is predominantly sensitive towards multivalent presentations of antigens. Consequently, when designing a vaccine, it is beneficial to garnish a nanostructured surface with multiple copies of an antigen so it can effectively act as an immune booster. Different methods are there for the development of the vaccine, from them most of the techniques are well developed and reported and some of in the developing state. This review focuses primarily on cellular and non-cellular vaccines, the whole cells or cellular proteins either as the source of antigens or the platform in which to deliver the antigens. Purpose of this review, understand and discussion on the various vaccine platforms which will contribute noteworthy information to vaccine research and development (R and D).
\end{abstract}

\section{Keywords}

Vaccine, platform, immune response, vaccination, development

\section{Introduction}

The native bacterial microflora inhabits the gastrointestinal tract (GIT) from birth and persists there throughout life. Roughly more than thousands of microbes are existing in the small and large intestine and they are obviously immunogenic [1,2]. The indication is strong that the massive majority of immunoglobulin (Ig) A plasma cells in normal human GIT are replying to the antigens of the flora, and while the flora is also accountable for fabricating the maximum amount of $\mathrm{T}$ cells which are existing in the GIT of in fine fettle people, the types of $\mathrm{T}$ cell reaction which the flora provokes are less well agreed [3]. General mechanism of immunity busting via, an antigen prompted stimulation of antigen-presenting cells (APCs); a link of innate and adaptive immune artilleries triggering $\mathrm{T}$ cell and $\mathrm{B}$ cell immunity by fundamental immunological pathways are characterized to show how vaccine prompted immune responses lead to the

(C) The Author(s) 2021. This is an Open Access article licensed under a Creative Commons Attribution 4.0 International License (https://creativecommons.org/licenses/by/4.0/), which permits unrestricted use, sharing, adaptation, distribution and reproduction in any medium or format, for any purpose, even commercially, as long as you give appropriate credit to the original author(s) and the source, provide a link to the Creative Commons license, and indicate if changes were made. 
eradication of viral infection [4] (Figure 1). Whichever vaccines are presently approved for human use can be classified into two types virus oriented or protein-oriented vaccines. The virus-based vaccines can contain a live-attenuated virus or deactivated virus which is no longer infective [5]. Live-attenuated virus vaccines are characteristically produced by passaging in cell culture awaiting it loses its pathogenic characteristic and may produce merely a mild infection on injection. Protein-oriented vaccines can contain a protein purified from the virus or recombinant protein, or virus-infected cells, or virus-like particles (VLPs). VLPs comprise the mechanical viral proteins essential to form a virus particle, but lack the viral genome and non-structural proteins. Protein-oriented vaccines need the addition of an adjuvant to prompt a strong immune response [6]. Nowadays, the coronavirus disease-19 (COVID-19) vaccines oriented on these classical platforms are in clinical trials as well as available in the market, some based on the whole-inactivated virus and some are based on the recombinant protein [1]. These classical vaccine platforms have subsidized to most important public health breakthroughs $[7,8]$.

Though, certain restrictions are accompanying numerous of these platforms that make them less responsive to speed up vaccine development in a pandemic. In the case of VLPs, it is only one antigenic protein, conformationally arranged in the shape of a particle to offer important epitopes for the immune system/cells. Large amounts of the virus would require to be grown under biosafety circumstances for a whole-inactivated vaccine; extensive safety study is mandatory to safeguard live-attenuated viruses are safe and do not straightforwardly return to the thoughtful influence of the usual microbial flora of the gut on the mucosal immune system [9-11].

It barely needs highlighting that the colonization of the gut by microbes after birth is probably the largest antigenic challenge an animal will experience. It is also important to emphasize that the normal flora in humans probably does not exist as a single entity. With over four hundred species of microbes in the human ileum and colon, there is significant scope for quantitative and qualitative heterogeneity among dissimilar persons [12]. Laboratory mice often have a limited, specific-pathogen-free flora, are often fed sterile food, and are usually used at a young age. Early in life, most people, experience gut microorganisms and pathogens modifications this response to a type I helper T (Th1) lymphocytes, possibly through the introduction of interleukin (IL)-12 [13, 14]. Among them, vaccination platforms are widely used and they can be developed by using different vaccination platform development techniques (Figure 1). In this review study, we have focus on the various aspects of COVID-19 vaccine development platforms and future COVID-19 vaccine development scope as well [15].

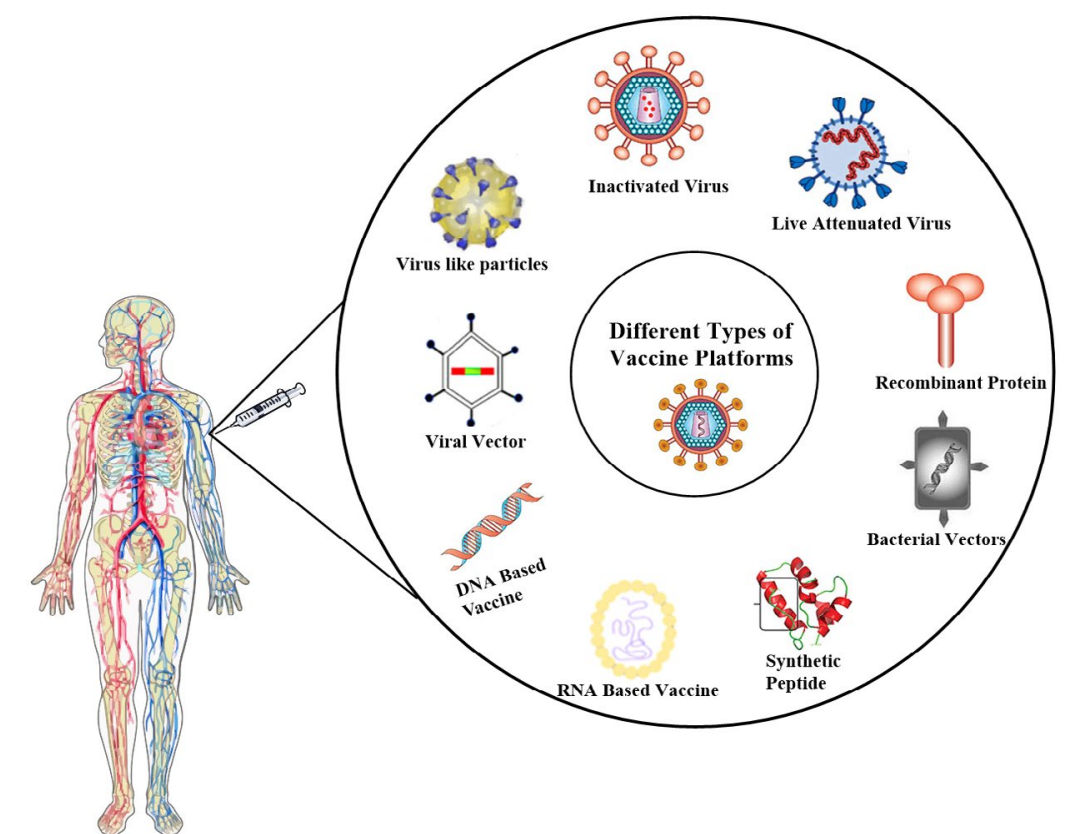

Figure 1. Different types of vaccination platforms for immunization. Vaccines can be developed using various platforms like an inactivated virus, live attenuated virus, recombinant-protein, bacterial vectors, synthetic peptides, RNA based, DNA based, viral vector, and virus-like particle [16]

Note. Adapted from "A COVID-19 vaccine: big strides come with big challenges" by Mellet J, Pepper MS. Vaccines (Basel). 2021;9:39. (https://www.ncbi.nlm.nih.gov/pmc/articles/PMC7827578/). CC BY. 


\section{Vaccination platforms}

An element that stimulates and triggers our immune system in contradiction of a specific disease and eradicates the pathogen, and protects us is called a vaccine. Numerous different kinds of vaccine development platforms exist, but the important functioning principle in all leftovers is the same. Vaccination permits the immune system to differentiate a pathogen and then initiate an immune response in contradiction of it [17]. At a later stage, when the body is exposed to a similar pathogen, immune machinery works to eradicate it from the body $[1,2]$. Nowadays we have so many platforms that are available to develop the vaccine like viral vector base immunization, nucleic acid-base [deoxyribonucleic acid (DNA) acid and Ribonucleic acid (RNA)], whole pathogen base, live attenuated, base immunization, and many more (Figure 1). All types of platforms are useful for the development of any type of vaccine.

\section{Replicating viral vector-based vaccine}

Replicating viral vectors deliver the vaccine antigen besides with retention of their capability to manufacturing new viral particles. The characteristic benefit of replicating viral vectors lies in their capability to assist as a constant source of vaccine antigen over a prolonged period and consequently activate a stronger immune response. Immunization of a single vaccine might be adequate to deliver protection. Ura et al. [18] described the details about the development of the viral-based vaccine. Same as nucleic acid vaccines, viral vectored vaccines engage the practice of harmless viruses for the delivery of target vaccine antigen genetic code to the body cells monitored by antigen protein construction and beginning of an immune response [19]. The manufacturing of viral vectored vaccines usages cell lines, and their large-scale development is rapid and easy. In the assessment of the nucleic acid vaccines and many subunit vaccines, the manufacture of viral vectored vaccines is significantly economical $[18,20]$. In this current COVID-19 pandemic situation several vaccines are developed by using this technique $[21,22]$.

\section{Nucleic acid (DNA/RNA) vaccine}

Nucleic acid vaccines vary from conventional vaccines in that in its place of supplying the protein antigen; they deliver genetic instructions of a particular antigen to the body. Resultantly, the cellular technology itself manufacturing the antigen and initiates the immune reaction. They can be developed rapidly and simply and hold the noteworthy potential to be employed in future vaccine development initiatives [23, 24]. Chen et al. [25] reported the development of the nucleic acid-based vaccine by Inovio Pharmaceuticals, and Curevac, which are discovering RNA vaccine platforms. Early defense is not required for DNA since of its relative stability in contrast to the messenger RNA (mRNA). A method called electroporation is used for administering DNA vaccines [26]. It simplifies cellular uptake of the DNA vaccine by using low-intensity electric waves. To activate an immune response, inside the cell nucleus, DNA is initially translated into mRNA [27], with its translation into antigen protein. Numerous DNA vaccines are being established, but no such approved vaccine is existing as of yet. In RNA vaccines (Figure 2), mRNA is existing in a protective casing of lipid membrane, which delivers defense and also helps as a medium of mRNA entry into the cells over cell membrane fusion [28]. Inside the cell, cellular machinery translates mRNA into an antigen (protein) which is short-lived but activates satisfactory immune response throughout that period and is then removed from the body after existence broken down naturally. RNA vaccines cannot be associated with human DNA. Two RNA vaccines, the Moderna and Pfizer BioNTech are authorized for emergency use worldwide [29, 30]. The correlation between the protections of most vaccines is antibody production, which is a central element in evaluating the immunogenicity of new vaccines. For certain infectious diseases, there are established levels of antibodies accepted by the World Health Organization (WHO) that can be used as an indicator of protective responses. This provides an opportunity to evaluate the performance of new mRNA vaccine candidates and compare them with licensed vaccines, where applicable. The main benefit with mRNA vaccines is that the produced protein will have the precise and same conformation and glycosylation as the alive pathogen and consequently favoring the growth of exact antibody specificities. Advantages of this type of vaccine are electroporation generates a strong immune response and made the usage of genetic series and does now no 
longer want to be cultured. Disadvantages are deemed to be safe, electroporation can be complicated and potentially problematic. No DNA-based vaccine has been previously produced [31-33].

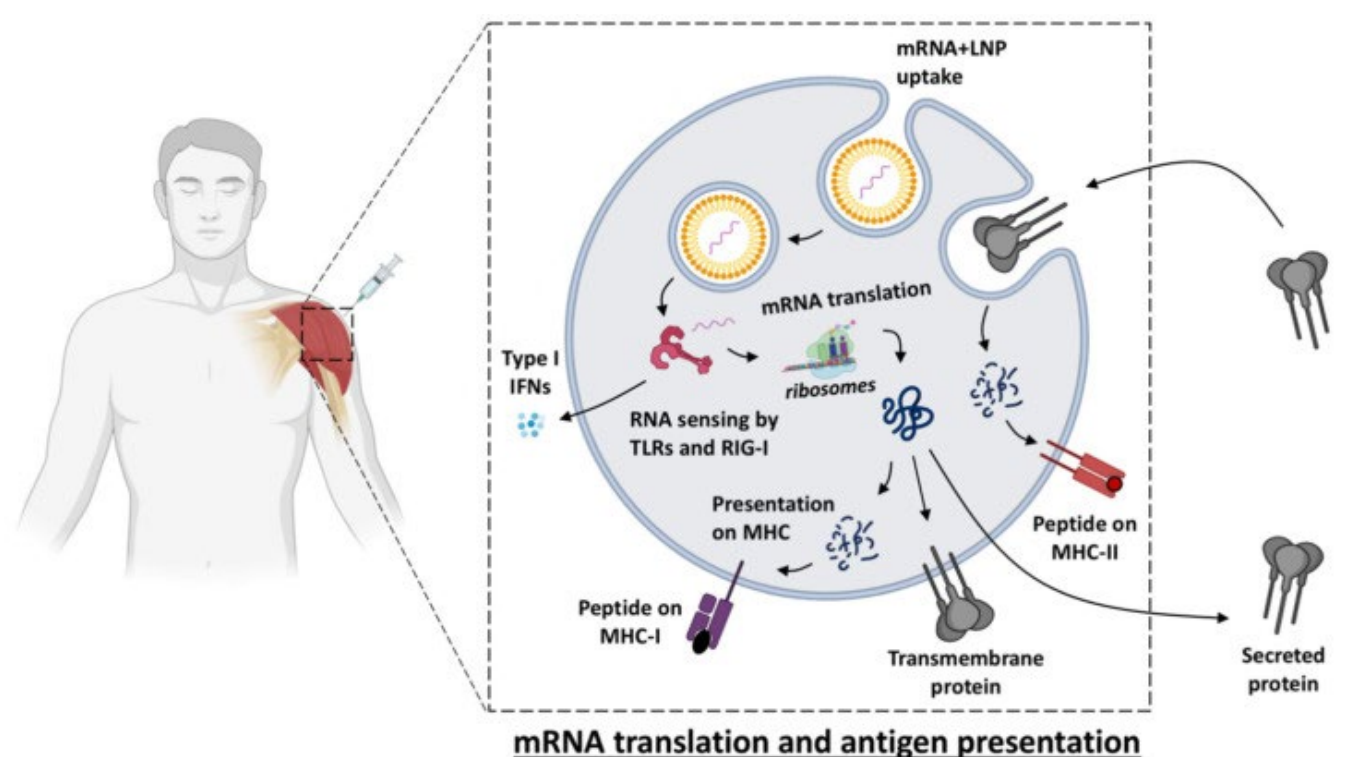

Figure 2. Vaccine uptake, translation, and biodistribution after mRNA vaccination [31]. IFNs: interferons; MHC: major histocompatibility complex; LNP: lipid nanoparticle; TLRs: toll-like receptors; RIG-1: retinoic acid-inducible gene 1

Note. Reprinted from "Immune responses induced by mRNA vaccination in mice, monkeys and humans" by Cagigi A, Loré K. Vaccines (Basel). 2021;9:61. (https://www.ncbi.nlm.nih.gov/pmc/articles/PMC7831080/). CC BY.

\section{Whole pathogen \live-attenuated vaccine}

Live-attenuated or inactive whole virus vaccines signify a classic approach for viral vaccinations. Most modern vaccines contain an attenuated pathogen that is sufficient to produce an immune response but does not trigger the disease in healthy individuals. Attenuation of the pathogen is achieved either as a naturally occurring phenomenon or through specific management of the pathogen genome by scientists [34]. To develop an immune response identical to a natural infection, the ancient and most recognized vaccination technique involved the usage of an entire disease-causing pathogen in a vaccine. As the conventional technique consisting of an active pathogen, consequently, the consequences of its danger to the recipient and potential contagiousness to the masses could not be ruled out. Hence, modern vaccines techniques make use of altered pathogens $[35,36]$.

\section{Inactivated vaccine}

Inactivated vaccines use the whole pathogens, i.e. viruses or bacteria, which may be utilized with whole or part of pathogen or killed to make them incompetent to replicate. Even in immune-compromised people, deactivated vaccines defend as they do not comprise the active pathogen. The vaccines for rabies, polio, flu, hepatitis A and Japanese encephalitis virus are some of the best examples of inactivated vaccines. The advantages of this type of vaccine are pathogens are killed and therefore, no risk of decline. Disadvantages are the risk of vaccine-enhanced disease and usually produce a weak immune response [33, 37-39].

\section{Subunit vaccine}

In most countries, vaccines manufactured are subunit vaccines. Characteristically, subunit vaccines comprise one or more precise antigens from the pathogen surface. Unlike the whole pathogen vaccines, the immune response works on the acknowledgment of a small number of antigen targets in subunit vaccines. Though, unlike live attenuated vaccines, the subunit vaccines do not activate a long-term immune response [40]. Primarily, repeated doses are mandatory, followed by booster doses in the subsequent years. Subunit vaccines often contain adjuvants, which permit the establishment and enlargement of the immune response in contradiction of the vaccine. Common local reactions like a sore arm are more frequently reported after the application of these types of vaccines [41-43]. 


\section{Recombinant protein vaccine}

Yeast or bacterial cells are used to make recombinant vaccines. A minor fragment of the pathogenic DNA is occupied and hosted into the manufacturing cells. For instance, the hepatitis B vaccine is made by introducing a small fragment of the hepatitis B virus (HBV) into the yeast cell DNA. This allows the yeast cells to manufacture surface proteins from the $\mathrm{HBV}$, which after purification, serves as an active ingredient of the vaccine. Acellular vaccines absent spatially organized whole cells and comprise proteins or polysaccharide sugars achieved from the pathogen surface, which are acknowledged as foreign antigens by the immune system. Although comprising a few thousand pathogenic proteins, these vaccines are adequate to defend in contradiction of the disease by initiating a suitable immune response [44, 45]. The vaccines for the human papillomavirus vaccine (HPV), HBV, and meningococcal serogroup B (MenB) use meningococcal bacterial surface proteins and are made by employing recombinant technology [46].

\section{VLPs}

VLPs are non-infectious molecules that look like viruses as they lack genetic material. They moreover occur naturally or result from the separate viral structural protein expression, monitored by self-assemble age into a virus-like structure [47]. Frequently, viral structural proteins act as antigens in a VLPs vaccine. The development of VLPs can be used to produce multiple pathogens at once or to existing foreign antigens on the cell surface [48]. A more effective immune response is stimulated by using VLPs, as in its place of a single copy, they produce multiple copies of the antigen on the virus surface. As adjuvants, the structural proteins of the VLPs reinforce the immune response in contradiction of the primary target antigen [49]. Certainly, bacteria produce a bleb of the bacterial outer plasma membrane called outer membrane vesicles (OMVs), which is a non-infectious particle but comprises numerous cell membrane antigens. OMV can be harvested from bacteria in a laboratory setting to be used as a vaccine. Alteration of the OMVs is done to eliminate the toxic antigens [50]. OMV act as natural adjuvants. As it is a novel vaccine platform, consequently licensed examples are scarce [51-53]. Data in the table indicating the different types of vaccine development platforms and their related pros and cons (Table 1).

Table 1. Vaccine platforms and their potential advantages and disadvantages [22]

\begin{tabular}{|c|c|c|c|}
\hline Vaccine platform & Advantages & Disadvantages & Existing vaccine examples \\
\hline Live-attenuated & $\begin{array}{l}\text { - Strong and long-lasting immune } \\
\text { response } \\
\text { - Broad antigenic profile }\end{array}$ & $\begin{array}{l}\text { - Potential risk of disease } \\
\text { - Requirement for biosafety facilities }\end{array}$ & $\begin{array}{l}\text { - Smallpox } \\
\text { - Tuberculosis (BCG) } \\
\text { - Measles } \\
\text { - Polio (OPV) }\end{array}$ \\
\hline Inactivated & - Broad antigenic profile & $\begin{array}{l}\text { - Reduced immune response } \\
\text { - Requirement for biosafety facilities } \\
\text { - Lower purity }\end{array}$ & $\begin{array}{l}\text { - Hepatitis A } \\
\text { - Polio (IPV) } \\
\text { - Rabies } \\
\text { - Influenza }\end{array}$ \\
\hline Protein subunit & $\begin{array}{l}\text { - Noninfectious } \\
\text { - Targeting key antigens }\end{array}$ & $\begin{array}{l}\text { - Limited capability in inducing } \\
\text { cell-mediated immunity } \\
\text { - Adjuvant often needed } \\
\text { - Challenges in large-scale } \\
\text { production }\end{array}$ & $\begin{array}{l}\text { - Hepatitis B (HBV) } \\
\text { - DTP (diphtheria, tetanus, } \\
\text { and pertussis) }\end{array}$ \\
\hline VLP & $\begin{array}{l}\text { - Noninfectious } \\
\text { - Broad antigenic profile }\end{array}$ & $\begin{array}{l}\text { - Limited immunogenicity } \\
\text { - Lower purity }\end{array}$ & $\begin{array}{l}\text { - Hepatitis B (HBV) } \\
\text { - Papillomavirus (HPV) }\end{array}$ \\
\hline $\begin{array}{l}\text { Nonreplicating } \\
\text { viral vector }\end{array}$ & $\begin{array}{l}\text { - Fast to produce } \\
\text { - Reusable platform } \\
\text { - Strong in both cell- and antibody- } \\
\text { mediated immune response }\end{array}$ & $\begin{array}{l}\text { - Pre-existing immunity against the } \\
\text { vector } \\
\text { - Risk of adverse reactions }\end{array}$ & N.A. \\
\hline
\end{tabular}


Table 1. Vaccine platforms and their potential advantages and disadvantages [22] (continued)

\begin{tabular}{|c|c|c|c|}
\hline Vaccine platform & Advantages & Disadvantages & Existing vaccine examples \\
\hline $\begin{array}{l}\text { Replicating viral } \\
\text { vector }\end{array}$ & $\begin{array}{l}\text { - Fast to produce } \\
\text { - Lower doses/single dose } \\
\text { - Reusable platform } \\
\text { - Strong in both cell- and antibody- } \\
\text { mediated immune response } \\
\text { - Less infectious }\end{array}$ & $\begin{array}{l}\text { - Pre-existing immunity against the } \\
\text { vector } \\
\text { - Risk of adverse reactions }\end{array}$ & \\
\hline DNA & $\begin{array}{l}\text { - Fast to produce } \\
\text { - Scalable } \\
\text { - Noninfectious } \\
\text { - Reusable platform } \\
\text { - Stable at room temperature }\end{array}$ & - May need special delivery devices & N.A. \\
\hline mRNA & $\begin{array}{l}\text { - Fast to produce } \\
\text { - Noninfectious } \\
\text { - No genome integration risk } \\
\text { - Reusable platform } \\
\text { - Stimulates strong T cell response } \\
\text { - Simple formulation }\end{array}$ & $\begin{array}{l}\text { - May need extremely low } \\
\text { temperature for storage and } \\
\text { transportation } \\
\text { - May need special delivery system }\end{array}$ & - COVID-19 (EUA) \\
\hline
\end{tabular}

N.A.: data not reported, EUA: Emergency Use Authorization; BCG: Bacille Calmette-Guerin; OPV: oral poliovirus vaccine; IPV: inactivated polio vaccine; DTP: diphtheria-tetanus-pertussis

Note. Reprinted from "A comprehensive review of the global efforts on COVID-19 vaccine development" by Li Y, Tenchov R, Smoot J, Liu C, Watkins S, Zhou Q. ACS Cent Sci. 2021;7:512-33. (https://www.ncbi.nlm.nih.gov/pmc/articles/PMC8029445/). CC BY ND.

\section{Toxoid vaccines}

Some bacteria release toxins upon entering the human body. The immune system recognizes these toxins as foreign antigens and triggers an appropriate immune response against them. Toxoid vaccines are made by using inactivated pathogenic toxins and are known as toxoids as they are not poisonous but mimic the toxin appearance [54]. These vaccines stir an appreciable immune response [55]. Examples of toxoid vaccines include the whooping cough vaccine, the diphtheria vaccine, and the tetanus vaccine [56]. Hajj Hussein et al. [57] reported detailed advances on the toxoid vaccines. Toxoid-containing vaccines are well-reported and explained in this article.

\section{Conjugate vaccine}

The word "conjugate" states to somewhat which is moreover "joined" or "connected". To get protected from certain bacteria, vaccines are essential to training the immune system, that in its place of targeting the proteins, they should react to the microbial surface polysaccharides or complex sugars. Later on, it was discovered that if the polysaccharide was conjugated to somewhat else, which can activate a stronger immune response, then their working effectiveness could be enhanced greatly. Most conjugate vaccines use tetanus or diphtheria toxoid proteins as conjugates to the polysaccharides [58]. These proteins are straightforwardly recognized by the immune system and assist in the generation of a stronger immune response in contradiction of bacterial polysaccharides. The diphtheria toxoid is frequently called cross-reacting material 197 (CRM197) carrier protein on product information since of its characteristic resemblances with the diphtheria toxoid. A conjugate vaccine called typhoid conjugate vaccine also happens for typhoid fever and has been established effectively by a study accompanied by the vaccine group of Oxford University [59, 60].

\section{Non-replicating viral vector vaccine}

During the delivery of the vaccine antigen to the cell, non-replicating viral vectors lose their ability to synthesize new viral particles, perhaps due to the in vitro removal of genes enabling viral replication. This technique is particularly advantageous as the vaccine is unable to trigger disease, and the cascade of events associated with replication of the viral vectors is minimized. Though its inadequacy to produce vaccine 
antigen except for the initial inoculum leftovers in infected cells makes the subsequent immune response to be short-lived and much weaker in contrast to the replicating viral vectors, and consequently, booster doses are desirable much likely. In last year, a viral vectored vaccine in contradiction of the ebola virus had been approved by the European Medicines Agency [61]. According to current updates, Johnson and Johnson is one of the few multinational pharma industries boarding on COVID-19 vaccines using this approach. A nonreplicating viral vector called ChAdOx1 is used in the COVID-19 vaccine mass-produced by the Oxford-Astra Zeneca, which achieved emergency authorization by the Medicines and Healthcare products Regulatory Agency (MHRA) in last of 2020. The advantage of this type of vaccine are can be manufactured on a large scale. Safe and effective immunologically as shown with Ebola. The disadvantage is pre-existing immunity could hamper clinical use and reduce immune response [33, 62-64].

\section{COVID-19 vaccine current status of development}

As per the available data, numerous approaches are implemented in the development of coronavirus vaccines; the maximum of this targets the surface open spike (S) glycoprotein or S protein as the main inducer of counteracting antibodies. Quite a lot of $S$ protein established approaches have been tried for evolving coronavirus vaccines, for example, the use of full-length S protein and expression in VLP, DNA, or viral vectors and so many $[65,66]$. Currently, more than 300 vaccines candidate is under development stage, and from them, 9 are permitted for emergency use in many countries like the USA, UK, India, Australia, China, Russia, and many more COVID affected countries $[67,68]$. These approved candidates showing impressive efficiency from $50 \%$ to $95 \%$. Recently, several new severe acute respiratory syndrome coronavirus-2 (SARS-CoV-2) variants have emerged and are circulating globally, and preliminary findings imply that some of them may escape immune responses against previous variants and diminish the efficacy of current vaccines. Most of these variants acquired new mutations in their surface protein which is the antigen in most of the approved/under development vaccines. It has been possible, because of tools for fast-tracked testing comprising small and large animal models for vaccine effectiveness analysis, assays for immunogenicity evaluation, critical reagents, international biological standards, these all things are made possible to accelerate the development of vaccines [21]. Following table presenting the compilation on current status of vaccine development throughout the world (Table 2).

Table 2. Current development status of COVID-19 vaccine

\begin{tabular}{|c|c|c|c|c|c|c|c|c|}
\hline $\begin{array}{l}\text { Sr } \\
\text { No }\end{array}$ & $\begin{array}{l}\text { Vaccine } \\
\text { platform }\end{array}$ & Country & Manufacturer & $\begin{array}{l}\text { Development } \\
\text { phase }\end{array}$ & $\begin{array}{l}\text { Route of } \\
\text { adminis- } \\
\text { tration }\end{array}$ & $\begin{array}{l}\text { Number } \\
\text { of doses }\end{array}$ & $\begin{array}{l}\text { Registration } \\
\text { number }\end{array}$ & References \\
\hline \multirow[t]{8}{*}{1} & \multirow{8}{*}{$\begin{array}{l}\text { Nucleic } \\
\text { acid (DNA/ } \\
\text { RNA) } \\
\text { Vaccine }\end{array}$} & India & $\begin{array}{l}\text { Cadila Healthcare } \\
\text { Limited }\end{array}$ & Phase 3 & ID & 3 & $\begin{array}{l}\text { ZyCoV-D } \\
(2541524-47-2)\end{array}$ & {$[33,69-71]$} \\
\hline & & Japan & $\begin{array}{l}\text { Osaka University/ } \\
\text { AnGes/Takara Bio }\end{array}$ & Phase 2/3 & IM & 2 & $\begin{array}{l}\text { AG0301-COVID19 } \\
\text { (2541593-92-2); } \\
\text { AG0302-COVID19 } \\
(2541593-93-3)\end{array}$ & \\
\hline & & USA & $\begin{array}{l}\text { Inovio } \\
\text { Pharmaceuticals/ } \\
\text { International Vaccine } \\
\text { Institute }\end{array}$ & Phase $2 / 3$ & ID & 3 & $\begin{array}{l}\text { INO-4800 } \\
(2535490-43-6)\end{array}$ & \\
\hline & & Italy & $\begin{array}{l}\text { Takis/Rottapharm } \\
\text { Biotech }\end{array}$ & Phase 1/2 & IM & * & COVID-eVax & \\
\hline & & Australia & $\begin{array}{l}\text { University of Sydney/ } \\
\text { Bionet Co Ltd } \\
\text { Technovalia }\end{array}$ & Phase 1 & IM & 2 & COVIGEN & \\
\hline & & $\begin{array}{l}\text { South } \\
\text { Korea }\end{array}$ & $\begin{array}{l}\text { GeneOne Life } \\
\text { science Inc }\end{array}$ & Phase 1/2 & ID & 2 & GLS-5310 & \\
\hline & & Canada & $\begin{array}{l}\text { Entos } \\
\text { Pharmaceuticals Inc }\end{array}$ & Phase 1 & $\mathrm{IM}$ & 2 & $\begin{array}{l}\text { Covigenix } \\
\text { VAX-001 }\end{array}$ & \\
\hline & & USA & $\begin{array}{l}\text { Providence Health } \\
\text { and Service }\end{array}$ & Phase 1 & ID & 2 & CORVax & \\
\hline
\end{tabular}


Table 2. Current development status of COVID-19 vaccine (continued)

\begin{tabular}{|c|c|c|c|c|c|c|c|c|}
\hline $\begin{array}{l}\text { Sr } \\
\text { No }\end{array}$ & $\begin{array}{l}\text { Vaccine } \\
\text { platform }\end{array}$ & Country & Manufacturer & $\begin{array}{l}\text { Development } \\
\text { phase }\end{array}$ & $\begin{array}{l}\text { Route of } \\
\text { adminis- } \\
\text { tration }\end{array}$ & $\begin{array}{l}\text { Number } \\
\text { of doses }\end{array}$ & $\begin{array}{l}\text { Registration } \\
\text { number }\end{array}$ & References \\
\hline & & Canada & Symvivo & Phase 1 & Oral & 1 & bac-TRL S & \\
\hline & & $\begin{array}{l}\text { South } \\
\text { Korea }\end{array}$ & Genexine Consortium & Phase $1 / 2$ & $\mathrm{IM}$ & 2 & $\begin{array}{l}\text { GX-19 } \\
(2541485678)\end{array}$ & \\
\hline & & India & $\begin{array}{l}\text { Cadila Healthcare } \\
\text { Limited }\end{array}$ & Phase 3 & ID & 3 & $\begin{array}{l}\text { ZyCov-D } \\
(2541524472)\end{array}$ & \\
\hline & & Japan & $\begin{array}{l}\text { Osaka University/ } \\
\text { AnGes/Takara Bio }\end{array}$ & Phase $2 / 3$ & IM & 2 & $\begin{array}{l}\text { AG0301-COVID } \\
19 \text { (2541593922), } \\
\text { AG0302-COVID } 19 \\
(2541593933)\end{array}$ & \\
\hline & & USA & $\begin{array}{l}\text { Inovio } \\
\text { Pharmaceuticals/ } \\
\text { International Vaccine } \\
\text { Institute }\end{array}$ & Phase $2 / 3$ & ID & 2 & $\begin{array}{l}\text { INO-4800 } \\
(2535490436)\end{array}$ & \\
\hline & & Canada & $\begin{array}{l}\text { Providence } \\
\text { Therapeutics }\end{array}$ & Phase 1 & IM & 2 & PTX-COVID 19-B & \\
\hline & & Thailand & $\begin{array}{l}\text { Chulangkorn } \\
\text { University }\end{array}$ & Phase 1 & IM & 2 & ChulaCov19 & \\
\hline & & China & $\begin{array}{l}\text { Shulan (Hangzhou) } \\
\text { Center for Disease } \\
\text { Control and } \\
\text { prevention of } \\
\text { Gaungxi Zhuang } \\
\text { Autonomous Region }\end{array}$ & Phase 1 & $\mathrm{IM}$ & 2 & $\begin{array}{l}\text { SARS-CoV-2 } \\
\text { mRNA vaccine }\end{array}$ & \\
\hline & & UK & $\begin{array}{l}\text { Imperial college } \\
\text { London }\end{array}$ & Phase 1 & $\mathrm{IM}$ & 2 & $\begin{array}{l}\text { LNP-nCoVsaRNA } \\
(2545641-90-3)\end{array}$ & \\
\hline & & $\begin{array}{l}\text { USA/ } \\
\text { Singapore }\end{array}$ & Arcturus/Duke-NUS & Phase 2 & ND & * & $\begin{array}{l}\text { ARCT-021 } \\
(2541451-24-3)\end{array}$ & \\
\hline & & Germany & Curevac & Phase 3 & IM & 2 & $\begin{array}{l}\text { CVNCOV } \\
(2541470-90-8)\end{array}$ & \\
\hline 2 & $\begin{array}{l}\text { Live- } \\
\text { attenuated } \\
\text { virus }\end{array}$ & India & $\begin{array}{l}\text { Codagenix/Serum } \\
\text { Institute of India }\end{array}$ & Phase 1 & IN & 2 & COVI-VAC & \\
\hline \multirow[t]{10}{*}{3} & $\begin{array}{l}\text { Inactivated } \\
\text { Virus }\end{array}$ & India & Bharat Biotech & Phase 3 & $\mathrm{IM}$ & 2 & $\begin{array}{l}\text { Covaxin/BBV152 } \\
(2501889-19-4)\end{array}$ & \\
\hline & & Iran & $\begin{array}{l}\text { Shifa Pharmed } \\
\text { Industrial Co }\end{array}$ & Phase 1 & $\mathrm{IM}$ & 2 & * & \\
\hline & & China & Sinovac & Phase 4 & $\mathrm{IM}$ & 2 & $\begin{array}{l}\text { CoronaVac } \\
(2480309-93-9)\end{array}$ & \\
\hline & & China & $\begin{array}{l}\text { Wuhan Institute of } \\
\text { Biological Products/ } \\
\text { Sinopharm }\end{array}$ & Phase 3 & $\mathrm{IM}$ & 2 & * & \\
\hline & & China & $\begin{array}{l}\text { Beijing Institute of } \\
\text { Biological Products/ } \\
\text { Sinopharm }\end{array}$ & Phase 3 & IM & 2 & $\begin{array}{l}\text { BBIBP-CorV } \\
(2503126-65-4)\end{array}$ & \\
\hline & & China & $\begin{array}{l}\text { Beijing Minhai } \\
\text { Biotechnology Co }\end{array}$ & Phase 2 & IM & $1-3$ & * & \\
\hline & & China & $\begin{array}{l}\text { Chinese Academy of } \\
\text { Medical Sciences }\end{array}$ & Phase 3 & IM & 2 & * & \\
\hline & & Kazakhstan & $\begin{array}{l}\text { Research Institute } \\
\text { for Biological Safety } \\
\text { Problems }\end{array}$ & Phase 3 & $\mathrm{IM}$ & 2 & $\begin{array}{l}\text { QazCovid-in } \\
(2541708-50-1)\end{array}$ & \\
\hline & & UK & $\begin{array}{l}\text { Valneva, National } \\
\text { Institute for Health } \\
\text { Research }\end{array}$ & Phase 1/2 & IM & 2 & VLA2001 & \\
\hline & & Turkey & Erciyes University & Phase 1 & IM & 2 & ERUCOV-VAC & \\
\hline \multirow[t]{2}{*}{4} & $\begin{array}{l}\text { Virus-Like } \\
\text { Particle }\end{array}$ & India & $\begin{array}{l}\text { SpyBiotech/Serum } \\
\text { Institute of India }\end{array}$ & Phase 1/2 & $\mathrm{IM}$ & 2 & * & \\
\hline & & Canada & Medicago Inc & Phase $2 / 3$ & $\mathrm{IM}$ & 2 & * & \\
\hline
\end{tabular}


Table 2. Current development status of COVID-19 vaccine (continued)

\begin{tabular}{|c|c|c|c|c|c|c|c|c|}
\hline $\begin{array}{l}\text { Sr } \\
\text { No }\end{array}$ & $\begin{array}{l}\text { Vaccine } \\
\text { platform }\end{array}$ & Country & Manufacturer & $\begin{array}{l}\text { Development } \\
\text { phase }\end{array}$ & $\begin{array}{l}\text { Route of } \\
\text { adminis- } \\
\text { tration }\end{array}$ & $\begin{array}{l}\text { Number } \\
\text { of doses }\end{array}$ & $\begin{array}{l}\text { Registration } \\
\text { number }\end{array}$ & References \\
\hline \multirow[t]{2}{*}{4} & $\begin{array}{l}\text { Virus-Like } \\
\text { Particle }\end{array}$ & India & $\begin{array}{l}\text { SpyBiotech/Serum } \\
\text { Institute of India }\end{array}$ & Phase 1/2 & $\mathrm{IM}$ & 2 & * & \\
\hline & & Canada & Medicago Inc & Phase 2/3 & IM & 2 & * & \\
\hline \multirow[t]{6}{*}{5} & $\begin{array}{l}\text { Replicat- } \\
\text { ing Viral } \\
\text { Vector }\end{array}$ & USA & Aivita Biomedical, Inc & Phase $1 / 2$ & IM & 1 & $\begin{array}{l}\text { Dendritic } \\
\text { cell vaccine } \\
\text { AV-COVID-19 }\end{array}$ & \\
\hline & & Thailand & $\begin{array}{l}\text { Mahidol University; } \\
\text { The Government } \\
\text { Pharmaceutical } \\
\text { Organization; } \\
\text { Icahn School of } \\
\text { Medicine }\end{array}$ & Phase $1 / 2$ & IM & 2 & $\begin{array}{l}\text { NDV-HXP-S, } \\
\text { Newcastle disease } \\
\text { virus vector }\end{array}$ & \\
\hline & & $\begin{array}{l}\text { South } \\
\text { Korea }\end{array}$ & Cellid Co, Ltd & Phase 1/2 & IM & 1 & AdCLD-CoV19 & \\
\hline & & China & $\begin{array}{l}\text { Jiangsu Provincial } \\
\text { Center for Disease } \\
\text { Prevention and } \\
\text { Control }\end{array}$ & Phase 2 & IN & 1 & $\begin{array}{l}\text { DelNS1-2019- } \\
\text { nCoV-RBD-OPT1 } \\
\text { (Intranasal } \\
\text { flu-based-RBD) }\end{array}$ & \\
\hline & & China & $\begin{array}{l}\text { Shenzhen } \\
\text { Geno-Immune } \\
\text { Medical Institute }\end{array}$ & Phase 1 & SC & 3 & $\begin{array}{l}\text { COVID-19/aAPC } \\
\text { vaccine }\end{array}$ & \\
\hline & & Israel & $\begin{array}{l}\text { Israel Institute for } \\
\text { Biological Research/ } \\
\text { Weizmann Institute of } \\
\text { Science }\end{array}$ & Phase $1 / 2$ & IM & 1 & VSV-S & \\
\hline \multirow[t]{12}{*}{6} & $\begin{array}{l}\text { Nonrepli- } \\
\text { cating viral }\end{array}$ & India & $\begin{array}{l}\text { Bharat Biotech } \\
\text { International Limited }\end{array}$ & Phase 1 & IN & 1 & BBV154 & \\
\hline & & USA & $\begin{array}{l}\text { ImmunityBio, Inc and } \\
\text { NantKwest Inc }\end{array}$ & Phase 1 & Oral & 1 & $\begin{array}{l}\text { hAd5-COVID-19/ } \\
\text { hAd5-S-Fusion+ } \\
\text { N-ETSD }\end{array}$ & \\
\hline & & USA & $\begin{array}{l}\text { Johnson and } \\
\text { Johnson }\end{array}$ & Phase 3 & IM & $1-2$ & $\begin{array}{l}\text { Ad26.COV2.S/ } \\
\text { JNJ-78436735 } \\
(2541607-046-7)\end{array}$ & \\
\hline & & USA & City of Hope & Phase 1 & IM & $1-2$ & $\mathrm{COH04S1}$ & \\
\hline & & USA & Vaxart & Phase 1 & Oral & 2 & $\begin{array}{l}\text { VXA-CoV2-1 } \\
(2543668-36-4)\end{array}$ & \\
\hline & & USA & Altimmune, Inc & Phase 1 & IN & $1-2$ & AdCOVID & \\
\hline & & UK & $\begin{array}{l}\text { University of Oxford/ } \\
\text { AstraZeneca }\end{array}$ & Phase 4 & IM & $1-2$ & $\begin{array}{l}\text { AZD1222; } \\
\text { ChAdOx1-S; } \\
\text { ChAdOx1 } \\
\text { nCoV-19 } \\
(2499737-08-3)\end{array}$ & \\
\hline & & Russia & $\begin{array}{l}\text { Gamaleya Research } \\
\text { Institute }\end{array}$ & Phase 3 & IM & 2 & $\begin{array}{l}\text { rAd26-S+rAd5-S/ } \\
\text { Gam-COVID-Vac/ } \\
\text { Sputnik V } \\
(2541629-85-8)\end{array}$ & \\
\hline & & China & $\begin{array}{l}\text { CanSino Biological } \\
\text { Inc/Beijing Institute of } \\
\text { Biotechnology }\end{array}$ & Phase 3 & IM & 2 & $\begin{array}{l}\text { Ad5 nCoV } \\
(2540656-88-8)\end{array}$ & \\
\hline & & Belgium & $\begin{array}{l}\text { ReiThera (Italy)/ } \\
\text { LEUKOCARE } \\
\text { (Germany)/ } \\
\text { Univercells }\end{array}$ & Phase 1 & IM & 1 & $\begin{array}{l}\text { Gard-CoV2 } \\
(2543636-44-6)\end{array}$ & \\
\hline & & Germany & $\begin{array}{l}\text { Ludwig-Maximilians- } \\
\text { University of Munich }\end{array}$ & Phase 1 & IM & 2 & $\begin{array}{l}\text { MVA-SARS-2-S } \\
(2543700-32-7)\end{array}$ & \\
\hline & & China & $\begin{array}{l}\text { Shenzhen Geno- } \\
\text { Immune Medical } \\
\text { Institute }\end{array}$ & Phase $1 / 2$ & SC \& IV & 1 & $\begin{array}{l}\text { LV-SMENP-DC } \\
\text { vaccine }\end{array}$ & \\
\hline
\end{tabular}


Table 2. Current development status of COVID-19 vaccine (continued)

\begin{tabular}{|c|c|c|c|c|c|c|c|c|}
\hline $\begin{array}{l}\text { Sr } \\
\text { No }\end{array}$ & $\begin{array}{l}\text { Vaccine } \\
\text { platform }\end{array}$ & Country & Manufacturer & $\begin{array}{l}\text { Development } \\
\text { phase }\end{array}$ & $\begin{array}{l}\text { Route of } \\
\text { adminis- } \\
\text { tration }\end{array}$ & $\begin{array}{l}\text { Number } \\
\text { of doses }\end{array}$ & $\begin{array}{l}\text { Registration } \\
\text { number }\end{array}$ & References \\
\hline \multirow[t]{18}{*}{7} & Protein & India & Biological E Ltd & Phase $1 / 2$ & $\mathrm{IM}$ & 2 & * & \\
\hline & & $\begin{array}{l}\text { USA and } \\
\text { Netherlands }\end{array}$ & $\begin{array}{l}\text { University Medical } \\
\text { Center Groningen + } \\
\text { Akston Biosciences } \\
\text { Inc }\end{array}$ & Phase 1/2 & $\begin{array}{l}\text { SC and } \\
\text { IM }\end{array}$ & 1 & $\begin{array}{l}\text { SARS-CoV-2- } \\
\text { RBD-Fc fusion } \\
\text { protein }\end{array}$ & \\
\hline & & USA & Novavax & Phase 3 & IM & 2 & $\begin{array}{l}\text { NVX-CoV2373 } \\
(2502099-58-1)\end{array}$ & \\
\hline & & USA & $\begin{array}{l}\text { Kentucky } \\
\text { Bioprocessing, Inc }\end{array}$ & Phase 1 & IM & 2 & $\begin{array}{l}\text { KBP-COVID-19/ } \\
\text { KBP-201 } \\
(2543206-35-3)\end{array}$ & \\
\hline & & $\begin{array}{l}\text { China/UK/ } \\
\text { USA }\end{array}$ & $\begin{array}{l}\text { Clover } \\
\text { Biopharmaceuticals } \\
\text { Inc/GSK/ } \\
\text { Dynavax }\end{array}$ & Phase 2/3 & IM & 2 & $\begin{array}{l}\text { SCB-2019 } \\
(2541906-99-2)\end{array}$ & \\
\hline & & France/UK & Sanofi Pasteur/GSK & Phase $1 / 2$ & IM & 2 & * & \\
\hline & & China & $\begin{array}{l}\text { Anhui Zhifei Longcom } \\
\text { Biopharmaceutical/ } \\
\text { Institute of } \\
\text { Microbiology, } \\
\text { Chinese Academy of } \\
\text { Sciences }\end{array}$ & Phase 3 & IM & $2 / 3$ & $\begin{array}{l}\text { ZF } 2001 \text { (2609662- } \\
31-7)\end{array}$ & \\
\hline & & China & $\begin{array}{l}\text { West China Hospital, } \\
\text { Sichuan University }\end{array}$ & Phase 2 & IM & 2 & * & \\
\hline & & $\begin{array}{l}\text { Australia/ } \\
\text { South } \\
\text { Korea }\end{array}$ & $\begin{array}{l}\text { Vaxine Pty Ltd/ } \\
\text { Medytox }\end{array}$ & Phase 1 & IM & 1 & $\begin{array}{l}\text { COVAX-19 } \\
(2543231-22-5)\end{array}$ & \\
\hline & & Cuba & $\begin{array}{l}\text { Center for Genetic } \\
\text { Engineering and } \\
\text { Biotechnology }\end{array}$ & Phase 1/2 & IM & 3 & $\begin{array}{l}\text { Soberana } 02 \\
(2543416-58-4)\end{array}$ & \\
\hline & & $\begin{array}{l}\text { Taiwan/ } \\
\text { USA }\end{array}$ & $\begin{array}{l}\text { Medigen Vaccine } \\
\text { Biologics } \\
\text { Corporation/NIAID/ } \\
\text { Dynavax }\end{array}$ & Phase 2 & IM & 2 & $\begin{array}{l}\text { MVC-COV1901 } \\
(2565776-92-1)\end{array}$ & \\
\hline & & Germany & $\begin{array}{l}\text { University Hospital } \\
\text { Tuebingen }\end{array}$ & Phase 1 & SC & 1 & $\begin{array}{l}\text { CoVAC-1 } \\
(2543517-71-9)\end{array}$ & \\
\hline & & Taiwan & $\begin{array}{l}\text { Adimmune } \\
\text { Corporation }\end{array}$ & Phase 1 & ND & * & * & \\
\hline & & Taiwan & $\begin{array}{l}\text { COVAXX (USA)/ } \\
\text { United Biomedical Inc } \\
\text { Asia }\end{array}$ & Phase $2 / 3$ & IM & 2 & $\begin{array}{l}\text { UB-612 (2543531- } \\
06-0)\end{array}$ & \\
\hline & & Russia & $\begin{array}{l}\text { FBRI SRC } \\
\text { VB VECTOR, } \\
\text { Rospotrebnadzor, } \\
\text { Koltsovo }\end{array}$ & Phase $1 / 2$ & IM & 2 & * & \\
\hline & & Canada & $\begin{array}{l}\text { University of } \\
\text { Saskatchewan }\end{array}$ & Phase 1/2 & IM & 2 & $\begin{array}{l}\text { COVAC-1 and } \\
\text { COVAC-2 subunit } \\
\text { vaccine (S protein) } \\
+ \text { SWE adjuvant }\end{array}$ & \\
\hline & & Iran & $\begin{array}{l}\text { Razi Vaccine and } \\
\text { Serum Research } \\
\text { Institute }\end{array}$ & Phase 1 & $\mathrm{IM} / \mathrm{IN}$ & 3 & $\begin{array}{l}\text { Razi Cov Pars, } \\
\text { recombinant S } \\
\text { protein }\end{array}$ & \\
\hline & & $\begin{array}{l}\text { South } \\
\text { Korea }\end{array}$ & $\begin{array}{l}\text { SK Bioscience Co, } \\
\text { Ltd }\end{array}$ & Phase 1/2 & IM & 2 & GBP510 & \\
\hline
\end{tabular}

*: data not reported; Sr No: serial number; Bio: biotechnology; IM: intramuscular; IN: intranasal; SC: subcutaneous; ID: intradermal; IV: intravenous; Ltd: limited; ND: not disclosed; Co: company; Inc: incorporated 


\section{Future prospects of vaccine development against COVID-19}

Currently, it is noticed that the virus rapidly going through the mutation process. Nowadays, many mutant variants were reported and it's becoming a new challenge to fight against the COVID-19 pandemic. The mutations take place rapidly in the $S$ and receptor binding motif of the virus, it will affect recombination events and other positive pressures, and that the receptor-binding motif is the most conflicting area of $\mathrm{S}$ which may lead to the occurrence of escape mutants. Variants with several S mutations have been noticed in India Brazil, South Africa, Denmark, UK, and the USA. Two Variants B.1.1.7 and B.1.351 which were first started in the UK and South Africa, correspondingly, have produced a great deal of concern regarding their potential impacts on vaccine efficacy [72]. Recent data from in vitro studies establish that vaccine sera from numerous diverse vaccines have meaningfully reduced neutralization activity in contradiction of variant B.1.351 associated with older viral sequesters although the sera display little or no reduced neutralization against variant B.1.1.7. Variant B.1.617 was first detected in India, at the last of October and has meanwhile spread to more than many other countries, including Australia. Phase III trial results from AstraZeneca and Novavax were publicized that the vaccines had high efficiency $(85.6 \%$ and $74.6 \%)$ in contradiction of the B.1.1.7 variant. However, in the future there may be many more mutation variants will arise, and to defeat them we have to develop a vaccine, which eradicates all types of variants in the future $[73,74]$. As per current literature, there is a crucial requirement to start the development of efficient forms of prominent vaccines to defend in contradiction of the B.1.351 variant and others, also to improve an agenda for extended genomic investigation and quick analysis of novel variants to produce actionable research. For instant response, the emerging variants, the Coalition for Epidemic Preparedness Innovations (CEPI) set up a combined project named "Agility" in corporation with Public Health England (PHE), National Institute for Biological Standards and Control (NIBSC), and the Global initiative on sharing all influenza data (GISAID), to permit the speedy biological evaluation of developing variants both in vitro and in vivo. The agility project's purpose is to deliver open-access high-quality reports on the biological suggestions of developing variants and notify the requirement for strain changes or alterations for vaccines to guarantee efficiency is sustained [30, 75-77].

\section{Conclusions}

In this review, we have described different vaccine platforms for the development of the vaccine. There are viral and non-viral vector based platforms available for vaccine development. Viral vectors have been explored for their application as vaccine antigen transporters. The use of replicating or non-replicating viruses as a platform to supply vaccine antigen. The main challenge to consider is the likely introduction of vector-specific immunity which consequently impairs the capability of viral vectors to provoke appropriate immune responses in contradiction of the antigen being conceded. Nevertheless, this problem can be prevented by accepting suitable vaccination approaches such as the use of viruses that do not spread in humans and the use of diverse virus serotypes for major and improvement vaccinations. Therefore, many viral-vectored vaccines, non-viral vector vaccines, and immunotherapeutic agents are presently being estimated and used in vaccine developments. Although the additional challenges regarding vaccine development are to be explored in the future.

\section{Abbreviations}

COVID-19: coronavirus disease-19

DNA: deoxyribonucleic acid

GIT: gastrointestinal tract

HBV: hepatitis B virus

mRNA: messenger RNA

OMVs: outer membrane vesicles

RNA: ribonucleic acid

S: spike 
SARS-CoV-2: severe acute respiratory syndrome coronavirus-2

VLPs: virus-like particles

\section{Declarations}

Acknowledgments

The authors want to acknowledge and thank their institute, MET's Institute of Pharmacy, BKC, Affiliated to Savitribai Phule Pune University, Adgaon, Nashik for providing technical support and facilities to complete this work.

\section{Author contributions}

EDA conceptualized the content of the manuscript and contributed in drafting the manuscript. SJK reviewed and edited the final manuscript.

\section{Conflicts of interest}

The authors declare that they have no conflicts of interest.

\section{Ethical approval}

Not applicable.

\section{Consent to participate}

Not applicable.

\section{Consent to publication}

Not applicable.

\section{Availability of data and materials}

Not applicable.

\section{Funding}

Not applicable.

\section{Copyright}

(C) The Author(s) 2021.

\section{References}

1. van Riel D, de Wit E. Next-generation vaccine platforms for COVID-19. Nat Mater. 2020;19:810-2.

2. Ura T, Yamashita A, Mizuki N, Okuda K, Shimada M. New vaccine production platforms used in developing SARS-CoV-2 vaccine candidates. Vaccine. 2021;39:197-201.

3. Keshavarz M, Mirzaei H, Salemi M, Momeni F, Mousavi MJ, Sadeghalvad M, et al. Influenza vaccine: where are we and where do we go? Rev Med Virol. 2019;29:e2014.

4. Jain S, Batra H, Yadav P, Chand S. COVID-19 vaccines currently under preclinical and clinical studies, and associated antiviral immune response. Vaccines (Basel). 2020;8:649.

5. Clem AS. Fundamentals of vaccine immunology. J Glob Infect Dis. 2011;3:73-8.

6. Jung EJ, Lee KH, Seong BL. Reverse genetic platform for inactivated and live-attenuated influenza vaccine. Exp Mol Med. 2010;42:116-21.

7. Vermaelen K. Vaccine strategies to improve anti-cancer cellular immune responses. Front Immunol. 2019;10:8.

8. Shin MD, Shukla S, Chung YH, Beiss V, Chan SK, Ortega-Rivera OA, et al. COVID-19 vaccine development and a potential nanomaterial path forward. Nat Nanotechnol. 2020;15:646-55. 
9. Forni G, Mantovani A. COVID-19 vaccines: where we stand and challenges ahead. Cell Death Differ. 2021;28:626-39.

10. Lurie N, Saville M, Hatchett R, Halton J. Developing COVID-19 vaccines at pandemic speed. N Engl J Med. 2020;382:1969-73.

11. Ahire ED, Talele SG, Shah HS. Nanoparticles as a promising technology in microbial pharmaceutics. In: Mahapatra DK, Talele SG, Haghi AK, editors. Applied pharmaceutical science and microbiology: novel green chemistry methods and natural products. New York: Apple Academic Press; 2020. p. 26.

12. Pickard JM, Zeng MY, Caruso R, Núñez G. Gut microbiota: role in pathogen colonization, immune responses, and inflammatory disease. Immunol Rev. 2017;279:70-89.

13. Basha S, Surendran N, Pichichero M. Immune responses in neonates. Expert Rev Clin Immunol. 2014;10:1171-84.

14. Strunk T, Currie A, Richmond P, Simmer K, Burgner D. Innate immunity in human newborn infants: prematurity means more than immaturity. J Matern Fetal Neonatal Med. 2011;24:25-31.

15. Nagy A, Alhatlani B. An overview of current COVID-19 vaccine platforms. Comput Struct Biotechnol J. 2021;19:2508-17.

16. Mellet J, Pepper MS. A COVID-19 vaccine: big strides come with big challenges. Vaccines (Basel). 2021;9:39.

17. Yaqub O, Castle-Clarke S, Sevdalis N, Chataway J. Attitudes to vaccination: a critical review. Soc Sci Med. 2014;112:1-11.

18. Ura T, Okuda K, Shimada M. Developments in viral vector-based vaccines. Vaccines (Basel). 2014;2:624-41.

19. Choi Y, Chang J. Viral vectors for vaccine applications. Clin Exp Vaccine Res. 2013;2:97-105.

20. Rollier CS, Reyes-Sandoval A, Cottingham MG, Ewer K, Hill AV. Viral vectors as vaccine platforms: deployment in sight. Curr Opin Immunol. 2011;23:377-82.

21. Kaur SP, Gupta V. COVID-19 vaccine: a comprehensive status report. Virus Res. 2020;288:198114.

22. Li Y, Tenchov R, Smoot J, Liu C, Watkins S, Zhou Q. A comprehensive review of the global efforts on COVID-19 vaccine development. ACS Cent Sci. 2021;7:512-33.

23. Ulmer JB, Mason PW, Geall A, Mandl CW. RNA-based vaccines. Vaccine. 2012;30:4414-8.

24. Delany I, Rappuoli R, De Gregorio E. Vaccines for the 21st century. EMBO Mol Med. 2014;6:708-20.

25. Chen WH, Strych U, Hotez PJ, Bottazzi ME. The SARS-CoV-2 vaccine pipeline: an overview. Curr Trop Med Rep. 2020:1-4.

26. Porter KR, Raviprakash K. Nucleic acid (DNA) immunization as a platform for dengue vaccine development. Vaccine. 2015;33:7135-40.

27. Deering RP, Kommareddy S, Ulmer JB, Brito LA, Geall AJ. Nucleic acid vaccines: prospects for non-viral delivery of mRNA vaccines. Expert Opin Drug Deliv. 2014;11:885-99.

28. Broderick KE, Humeau LM. Enhanced delivery of DNA or RNA vaccines by electroporation. In: Kramps T, Elbers K, editors. RNA vaccines. New York: Humana Press; 2017. pp. 193-200.

29. Ho W, Gao M, Li F, Li Z, Zhang XQ Xu X. Next-generation vaccines: nanoparticle-mediated DNA and mRNA delivery. Adv Healthc Mater. 2021;10:e2001812.

30. Shahcheraghi SH, Ayatollahi J, Aljabali AA, Shastri MD, Shukla SD, Chellappan DK, et al. An overview of vaccine development for COVID-19. Ther Deliv. 2021;12:235-44.

31. Cagigi A, Loré K. Immune responses induced by mRNA vaccination in mice, monkeys and humans. Vaccines (Basel). 2021;9:61.

32. Bettini E, Locci M. SARS-CoV-2 mRNA vaccines: immunological mechanism and beyond. Vaccines (Basel). 2021;9:147. 
33. Rawat K, Kumari P, Saha L. COVID-19 vaccine: a recent update in pipeline vaccines, their design and development strategies. Eur J Pharmacol. 2021;892:173751.

34. Toussaint B, Chauchet X, Wang Y, Polack B, Le Gouëllec A. Live-attenuated bacteria as a cancer vaccine vector. Expert Rev Vaccines. 2013;12:1139-54.

35. Stern PL. Key steps in vaccine development. Ann Allergy Asthma Immunol. 2020;125:17-27.

36. Bonanni P, Santos JI. Vaccine evolution. Perspect Vaccinology. 2011;1:1-24.

37. Gao Q, Bao L, Mao H, Wang L, Xu K, Yang M, et al. Development of an inactivated vaccine candidate for SARS-CoV-2. Science. 2020;369:77-81.

38. Jafari H, Deshpande JM, Sutter RW, Bahl S, Verma H, Ahmad M, et al. Polio eradication. Efficacy of inactivated poliovirus vaccine in India. Science. 2014;345:922-5.

39. Okayasu H, Sutter RW, Jafari HS, Takane M, Aylward RB. Affordable inactivated poliovirus vaccine: strategies and progress. J Infect Dis. 2014;210 Suppl 1:S459-64.

40. Vartak A, Sucheck SJ. Recent advances in subunit vaccine carriers. Vaccines (Basel). 2016;4:12.

41. Schiller JT, Lowy DR. Raising expectations for subunit vaccine. J Infect Dis. 2015;211:1373-5.

42. Tan M, Jiang X. Recent advancements in combination subunit vaccine development. Hum Vaccin Immunother. 2017;13:180-5.

43. Jaume M, Yip MS, Kam YW, Cheung CY, Kien F, Roberts A, etal. SARS CoV subunit vaccine: antibody-mediated neutralisation and enhancement. Hong Kong Med J. 2012;18 Suppl 2:31-6.

44. Cox MM. Recombinant protein vaccines produced in insect cells. Vaccine. 2012;30:1759-66.

45. Pollet J, Chen WH, Strych U. Recombinant protein vaccines, a proven approach against coronavirus pandemics. Adv Drug Deliv Rev. 2021;170:71-82.

46. Sanders H, Feavers IM. Adjuvant properties of meningococcal outer membrane vesicles and the use of adjuvants in neisseria meningitidis protein vaccines. Expert Rev Vaccines. 2011;10:323-34.

47. Ludwig C, Wagner R. Virus-like particles-universal molecular toolboxes. Curr Opin Biotechnol. 2007;18:537-45.

48. Fuenmayor J, Gòdia F, Cervera L. Production of virus-like particles for vaccines. N Biotechnol. 2017;39:174-80.

49. Lua LH, Connors NK, Sainsbury F, Chuan YP, Wibowo N, Middelberg AP. Bioengineering virus-like particles as vaccines. Biotechnol Bioeng. 2014;111:425-40.

50. Mohsen MO, Speiser DE, Knuth A, Bachmann MF. Virus-like particles for vaccination against cancer. Wiley Interdiscip Rev Nanomed Nanobiotechnol. 2020;12:e1579.

51. Noad R, Roy P. Virus-like particles as immunogens. Trends Microbiol. 2003;11:438-44.

52. Boigard H, Alimova A, Martin GR, Katz A, Gottlieb P, Galarza JM. Zika virus-like particle (VLP) based vaccine. PLoS Negl Trop Dis. 2017;11:e0005608.

53. Frietze KM, Peabody DS, Chackerian B. Engineering virus-like particles as vaccine platforms. Curr Opin Virol. 2016;18:44-9.

54. Angsantikul P, Fang RH, Zhang L. Toxoid vaccination against bacterial infection using cell membrane-coated nanoparticles. Bioconjug Chem. 2018;29:604-12.

55. Hu CM, Zhang L. Nanotoxoid vaccines. Nano Today. 2014;9:401-4.

56. Jones RG, Liu Y, Rigsby P, Sesardic D. An improved method for development of toxoid vaccines and antitoxins. J Immunol Methods. 2008;337:42-8.

57. Hajj Hussein I, Chams N, Chams S, El Sayegh S, Badran R, Raad M, et al. Vaccines through centuries: major cornerstones of global health. Front Public Health. 2015;3:269.

58. Bremer PT, Janda KD. Conjugate vaccine immunotherapy for substance use disorder. Pharmacol Rev. 2017;69:298-315. 
59. Paradiso PR. Pneumococcal conjugate vaccine for adults: a new paradigm. Clin Infect Dis. 2012;55:259-64.

60. Black SB, Shinefield HR, Hansen J, Elvin L, Laufer D, Malinoski F. Postlicensure evaluation of the effectiveness of seven valent pneumococcal conjugate vaccine. Pediatr Infect Dis J. 2001;20:1105-7.

61. Robert-Guroff M. Replicating and non-replicating viral vectors for vaccine development. Curr Opin Biotechnol. 2007;18:546-56.

62. Belete TM. A review on promising vaccine development progress for COVID-19 disease. Vacunas. 2020;21:121-8.

63. Jeyanathan M, Afkhami S, Smaill F, Miller MS, Lichty BD, Xing Z. Immunological considerations for COVID-19 vaccine strategies. Nat Rev Immunol. 2020;20:615-32.

64. Haidere MF, Ratan ZA, Nowroz S, Zaman SB, Jung YJ, Hosseinzadeh H, et al. COVID-19 vaccine: critical questions with complicated answers. Biomol Ther (Seoul). 2021;29:1-10.

65. Dhama K, Sharun K, Tiwari R, Dadar M, Malik YS, Singh KP, et al. COVID-19, an emerging coronavirus infection: advances and prospects in designing and developing vaccines, immunotherapeutics, and therapeutics. Hum Vaccin Immunother. 2020;16:1232-8.

66. Rabaan AA, Al-Ahmed SH, Sah R, Tiwari R, Yatoo MI, Patel SK, et al. SARS-CoV-2/COVID-19 and advances in developing potential therapeutics and vaccines to counter this emerging pandemic. Ann Clin Microbiol Antimicrob. 2020;19:40.

67. COVID-19 vaccine tracker [Internet]. Rockville: Regulatory Affairs Professionals Society (RAPS); c2021 [cited 2021 Sep 8]. Available from: https://www.raps.org/news-and-articles/news-articles/2020/3/ covid-19-vaccine-tracker

68. COVID-19 vaccines [Internet]. World Health Organization; c2021 [cited 2021 Sep 8]. Available from: https://www.who.int/emergencies/diseases/novel-coronavirus-2019/covid-19-vaccines

69. Brisse M, Vrba SM, Kirk N, Liang Y, Ly H. Emerging concepts and technologies in vaccine development. Front Immunol. 2020;11:583077.

70. Kyriakidis NC, López-Cortés A, González EV, Grimaldos AB, Prado EO. SARS-CoV-2 vaccines strategies: a comprehensive review of phase 3 candidates. NPJ Vaccines. 2021;6:28.

71. Chung YH, Beiss V, Fiering SN, Steinmetz NF. COVID-19 vaccine frontrunners and their nanotechnology design. ACS Nano. 2020;14:12522-37.

72. Lurie N, Sharfstein JM, Goodman JL. The development of COVID-19 vaccines: safeguards needed. JAMA. 2020;324:439-40.

73. Kashte S, Gulbake A, El-Amin Iii SF, Gupta A. COVID-19 vaccines: rapid development, implications, challenges and future prospects. Hum Cell. 2021;34:711-33.

74. Kabir MA, Ahmed R, Chowdhury R, Iqbal SMA, Paulmurugan R, Demirci U, etal. Management of COVID-19: current status and future prospects. Microbes Infect. 2021;23:104832.

75. Bharadwaj KK, Srivastava A, Panda MK, Singh YD, Maharana R, Mandal K, et al. Computational intelligence in vaccine design against COVID-19. In: Raza K, editor. Computational intelligence methods in COVID-19: surveillance, prevention, prediction and diagnosis. Germany: Springer; 2021. pp. 311-29.

76. Borah P, Deb PK, Deka S, Venugopala KN, Singh V, Mailavaram RP, et al. Current scenario and future prospect in the management of COVID-19. Curr Med Chem. 2021;28:284-307.

77. Borah P, Deb PK, Al-Shar'i NA, Dahabiyeh LA, Venugopala KN, Singh V, et al. Perspectives on RNA vaccine candidates for COVID-19. Front Mol Biosci. 2021;8:635245. 